\title{
Political Involvement among Youth in Malaysia: Lessons Learnt
}

\author{
Zalinah Ahmad \\ zalinah@uum.edu.my \\ School of Government, UUM COLGIS \\ Universiti Utara Malaysia \\ Zawiyah Mohd Zain \\ zmzain@uum.edu.my \\ School of Government, UUM COLGIS \\ Universiti Utara Malaysia
}

\begin{abstract}
Youth are asset for the country and their ideas may provide significant contribution towards the country development process. They are the driving force towards the progress of the country and their contributions are undeniable in providing new ideas. Other than as the human capitals provided for the workforce, youth are also backbone of the country. Youth involvement in politics happen throughout the world and Malaysia has no exception. Youth have voice out their concern on the government's policies and actions in the developing process by using available platform such as social media other than joining political parties or any association specifically for youth. The opportunities should be given to this group since country will lose creative, dynamic and innovative ideas from this group, known as Generation Y. The tagline like young leaders have created phenomena to give them opportunities to be leader at every level of government (community, state as well as country). This article will discuss the political involvement based on the survey among students in Universiti Utara Malaysia. Finding showed that internet specifically social media has attracted the respondents to know more about politics. Their lower involvement in political parties' activities are quite contradictory with their willingness to vote and encourage others to vote during the election process in Malaysia. This paper highlights the importance of social media as a platform for gaining youth involvement in political scenario in Malaysia. This paper also contributes to the comparative research on youth involvement in politics in Malaysia.
\end{abstract}

Keywords: Youth; social media; internet; political activities; political involvement;

\section{INTRODUCTION}

Youth involvement in politics is important because they are active group of people in everyday life with the age of 15 between 35 . Their involvement in politics can make a better quality of democratic government. Therefore, all government around the world including Malaysia should encourage their young people to participate more in government activities as well as involvement in politics like joining political parties, political discussion, belonging to activist group, voting and etc. 
Malaysian population is 32.7 million in year 2020 and almost half of the population are within the youth group. Based on the Statistic Department, total of youth in Malaysia in year 2018 is 15.1 million or 46.64 percent from total population Malaysia (Berita Harian, 2019). In other words, youth represent almost half of the total population in Malaysia. Besides, this group also has been known as their openness on new technology especially on usage of social media. Known as Generation Y, this group actively involves in using internet to get information and voice out their ideas and comments. The question is to what extent youth or generation $\mathrm{Y}$ involve in politics? The involvement of youth or Generation Y in politics is significant because this group represents almost half of the total voters in Malaysia. For example, the outcome of the Malaysian general election in 2018, won by the opposition, was contributed by the youth. Furthermore, in July 2019 the Parliament of Malaysia passed a Constitutional (amendment) bill 2019 to lower the eligible age of voting from 21 to 18 years old. Automatic registration for voters aged 18 and lower the qualifying age to be a member of the House of Representatives and state assemblyman from 21 to 18 is also approved in the Parliament. The amendment shows the significant contribution among youths in Malaysian political scenario. In addition, other countries also are finding ways to modify the legal framework in allowing the youth to govern the country by doing some amendments towards their political structure. Other changes that can be made is through civil society organizations and political parties to enhance awareness among youth to participate actively in politics.

The paper begins with the discussion on youth policy and political involvement in Malaysia. The discussion on social media is also included since it serves as platform for this group to voice out concerns and ideas about Malaysian scenario. Then, the paper discusses on the findings of the research. Finally, the paper concludes for active political involvement among youth in Malaysia.

\section{LITERATURE REVIEW}

The number of youths will increase significantly in coming years. In realizing the importance of youth, Malaysian government has introduced National Policy on Youth, known as National Policy on Youth Development in 1997 and further modified in year 2017 known as Malaysian Youth Policy (MYP). As previously mentioned, youth is an asset and backbone for the country. Malaysian government initiated the National Youth Policy (NYP) in 1985. The policy served as platform for Malaysian government to plan and implement programs related to youth. After 10 years, the government under the Ministry of Youth and Sports reviewed the policy and provided new policy, known as the National Youth Development Policy (NYDP). The policy was officially launched in year 1997. The NYDP had identified the role of youth as stimulus for nation development towards achieving developed nation by year 2020 .

Realizing the important role of youth, there is a chapter in $7^{\text {th }}$ Malaysian Plan (19962000) focused on youth and development. However, programs for this group had started since $6^{\text {th }}$ Malaysian Plan (1990-1995). The programs focused on role and participation of youths in national development. The $8^{\text {th }}$ Malaysian Plan (2001-2005) continued the approach in the previous plans implemented programs specifically for youth to gain skills and be entrepreneurs. The focus during the $8^{\text {th }}$ Malaysian Plan was to equip youth with necessary knowledge and skills to face the challenges due to economic development and globalization. The $9^{\text {th }}$ Malaysian Plan (2006-2010) emphasized on empowering youth to enhance their role in community. In doing so, the programs concentrated on leadership skills other than entrepreneurial skills. 
During this period, there were 380,090 youths had participated leadership training programs in various training institutions for youth. The $10^{\text {th }}$ Malaysian Plan (2011-2015) and the $11^{\text {th }}$ Malaysian Plan aimed to enhance role and participation of youth in national level as well as community level. Both plans continued the implementation of programs targeted to youth in developing their leadership and entrepreneurial skills as well as being good model of citizen.

In preparing the country to be developed nation in year 2020, MYP was launched in year 2018 as one of government effort on promoting transformation programs towards national development. The goals of the MYP are as following:

i) Increase the involvement of youth as responsible citizens in the initiatives formulated by policy stakeholders at the national, regional and international levels

ii) Highlight the potential of each individual youth by highlighting everyone's diversity and differences

iii) Expand the access to the priority areas and youth development initiatives for the benefit of all target groups

Besides the national policy, all activities involved youth are also under the umbrella of Youth Development and Societies Act 2007 (Act 688). These two documents under the responsibility of the Ministry of Youth and Sport. The MYP has been formulated based on four concepts and one of the concepts is defining the age limit to identify the youth group. The new policy has introduced the new age limit for youth which are within the age of 15 and 30 years old in 2018 and this new age limit applied to all youth societies in Malaysia. Previously, youth can be defined as any individual within the age of 15 and 40 years old as stated in Section 2 of Youth Society and Youth Development Act 2007. For instance, United Nations has defined youth group belongs to individual within the age of 15 to 24 years old (Marshelayanti et al, 1985) while Ministry of Youth and Sport tend to include those individual within the age of 15 and 40 to be part of its interpretation on any individuals to join the programs under the Ministry. Youth also can be viewed for those within the age of 15 and 30 as stated by Tuan Pah Rokiah et al (2016). With the new introduction policy on youth in year 2017, the ministry is consistent to include on any individuals within the age of 15 and 40 years old to be eligible to join the program under the Ministry, such as registration under e-belia. E-belia (e-youth) is the one stop portal for all Malaysian citizens within the age 15 to 40 years old to get information on trainings and skills development; business opportunities and other relevant information related to youth. The portal is considered as gateway for youth to explore opportunities provided by government and also private sectors.

Since youths are the group that governs the country in future, do youth actively involve $\mathrm{n}$ the political activities as a preparation for the role that they will undertake in future? There are many factors that may influence youth understanding about politics. Parents can be one of the influential factors since their beliefs on politics may influence their children 's perspectives on politics (Sihabuddin Zuhri, 2010). Other factors may influence the political beliefs among youth are peers, education, social media as well as mass media (Judith Moeller \& Claes de Vreese, 2013; Nam Jin Lee et al, 2012). Based on Malaysian Youth Score Index 2015, youth are more comfortable to discuss and communicate about political issues with friends or peers, family members and teachers or lecturers as compared to directly involve in political fields (Nor Anita, 2017). Young voters are more likely know more about current issues on politics 
from mass media other than their parents, school and friends (Kathryn, 2004). Mass media like internet is considered as main information gathering compared to other media like news, academic article or newspaper; social media like Facebook and twitter are two platform that gained the highest ratings among youth group (Noor Azma, 2014). According to Abu Elsnar, Mohamed, Parvis \& Mahmood Khan (2016), social media consists of activities namely watching news, attending virtually the public discussion and forum, communication with friends and playing games. The content of discussion or interaction results from the interactive social environment. According to Saleem \& Mengyan (2017), social media is an internet-based channel used to communicate personally in mass in which the individuals use computermediated communication to generate content of their own as well as interact with other profiles or users. Social media has been defined as internet-based communication and continuous communication among users a space. It can be any forms of communication via computer or mobile phone in which the users will develop his or her profile in order to ease the interaction with other users (Carr \& Hayes, 2015).

There are number of ways to involve in politics like campaigning, voting, sign petition, join political parties and participate in a political forum. Involvement in the political parties like being a member is the basic for direct involvement in political activities since being a member in political parties shows his commitment to openly support the party (Hussain, 1974). In Malaysia, Universities and University Colleges Act (AUKU) 1971 has been introduced towards restriction on students' involvement in political activities. In 2012, the government has lifted some of the restriction on students' involvement in political activities. The students' involvement can be seen in activities such as joining demonstration, memorandum, and political campaign and dialogue. Even though some of the restrictions has been lifted, the students' involvement in political activities are still lower. According to Fazurawati (2018), many university students may not have awareness on political issues organized by political parties unless the university's administration required students to attend such program. Research done by Mazli, Abdul Razak \& Abdul Rashid (2019) showed that very few Malay students to be a member of political parties in which $72(16.3 \%)$ respondents from the total of 411 respondents join political parties. Studies done among women in Perak showed that majority of respondents (92.4\% out of 416 respondents) did not involve with political parties and very few of the respondents involve in any political parties (7.6\% out of 34 respondents). This finding showed that involvement in any political parties is even lower among public in general (Siti Noranizahhafizah, 2019).

In order to influence youth in their political choices, political parties should opt for using social media to influence youth political choices. For instance, political candidates may have limited control over how mainstream news media may frame the election. Therefore, they are using social media as a platform to design and provide alternative election narratives (Howard, 2006; Kreiss, 2012). Candidates have adopted digital communication for strategic purposes, allowing supporters to engage with the campaign. The use of internet in Malaysia as a part of political campaign has been widely applied since the reformed era, known as Reformasi, in which, after Anwar Ibrahim was sacked from cabinet in 1998. His supporters switched to alternative media, namely Internet because government restricted the issue to be broadcast in main media. The popular application during reformed era and 1999 general 
election was website. With the development of technology, there have various applications of social media likes blogs, Linked in, You Tube, Twitter, Facebook and Instagram.

Political involvement is how an individual involve or convinced others to join the political activities by exercising their rights (Monroe, 2002). The election scenario in Malaysia in which youth are the entity that both governing party and opposition party will try to persuade in their efforts to win election. Several elections in Malaysia has witnessed how youth has contributed towards winning political party. It can be drawn since $12^{\text {th }}$ general election until $14^{\text {th }}$ general election (Yazid, 2020). In addition, youth involvement in NGOs is also low at university level (Abdul Hadi, 2013) before the changes that has been made on University and College Act (AUKU). As study done by Fauzi and Ku Hasnita (2015), university students actively involved in national election campaign in year 2013 after the government has agreed to change the AUKU in year 2012.

Research by Norshuhada et al. (2016) showed, young people are majority comprised of generation $\mathrm{Y}$ which is a generation that leverages technology in all aspects of life. Generation $\mathrm{Y}$, according to them, has full trust in the mass media as a platform to bridge the gap between the people and the government especially involvement in decision making and delivering opinions. Generation Y became the main target of the government and also the opposition in pursuing their support. Jamaie Hj Hamil (2014) analyzed the Malaysian General Election from 1978 to 2013. BN's slim victory in the 1999 PRU was said to be one of the forms of protests and people's objections to an autocratic and too long-leading government. Furthermore, other factors affecting the scenario were also due to more modern young voters with extensive knowledge in politics.

Mohd Fuad et. al (2012) examined the political perception of Indian youth in Public Institutions of Higher Learning namely Universiti Kebangsaan Malaysia (UKM), Universiti Putra Malaysia (UPM), and Universiti Malaya. The study found that the respondents believed that Malaysian Indian Congres (MIC) was the only political party representing Indians who were able to defend their current and future fortunes. The findings also showed that Indian youth still support MIC and BN but in the hope that the issue of Indian society is resolved well. Subsequently, the perception of Indian youth on political issues was similar to other ethnicities but more biased to their own ethnic issues such as educational issues, scholarships, religions and socioeconomic issues. Besides that, they are also exposed to contemporary political issues occurring in the country

According to Kitanova (2019) youth engagement in different modes of political participation varies significantly across distinctive democracies. Finding by Kitanova showed that there was different level of youth participation across the EU countries. Youth in newly established democracies are significantly lower compare to advance democracy there are more likely to be politically active. The study also revealed that the older people (25-30) tend to participate in any kind of formal politics compare to younger (18-25).

\section{RESEARCH METHODOLOGY}

The article is based on the research that had been carried out among students in Universiti Utara Malaysia (UUM). The questionnaire was developed based on the instruments and research done (Abdul Hadi Samsi (2013); Mohd Fuad Mat Jalil (2011); Marshelayanti Mohamad Razali 
(2016) and Yazid Salleh (2020)). The overall objective of the research is to explore the polticial involvement among youth by focusing on UUM students. The specific objectives are to explore forms of political involvements among respondents; identify factors that may encourage respondents to involve in politics and finally, to understand the characteriscs of political parties chosen by respondents. In doing so, there are four sections in the survey which are the demographic background of the respondents, forms of political involvement, factors influence youth political involvement and characteristics of political parties that may influence the choice of the youth. However, for the purpose of the article, the paper discussed three sections which are demographic background, forms of political involvement and factors influence youth to involve in politics. In doing so, the survey has been carried out by providing the link via social media platform like facebook, whatsapp and telegram as well. In return, there were 160 respondents have answered the survey.

\section{DISCUSSION AND CONCLUSION}

This section discussed on findings based on the questionnaire that has been distributed among respondents. There are 75 males and 85 female students have answered the survey. Majority of the respondents within the age of 18 and 22 (47\%) and also within the age of 23 and 27 $(49 \%)$. The rest of the respondents are within the age of 28 to $32(4 \%)$. Majority of the respondents were Malay (67\%) followed by Chinese (16\%), Indians (16\%) and other (1\%). Most of these students are in their $4^{\text {th }}$ year and $2^{\text {nd }}$ year students which are $56 \%$ and $26 \%$, respectively. The parents' occupations are varied in which there is no dominant sector in their occupation category. There are $28 \%$ of their parents work in government while $29 \%$ of respondents' parents work at private sector. The difference is only $1 \%$. Interestingly, $36 \%$ of respondents' parents are self-employed. This indicate that whether their parents owned business, or working at informal sectors. The demographic background of the respondents can be summarized in the following table.

TABLE 1 Demographic Background of Respondents

\begin{tabular}{|c|c|}
\hline Demographic Background & Percentage \\
\hline Male & $47 \%$ \\
\hline Female & $53 \%$ \\
\hline Age Range: $18-22$ & $47 \%$ \\
\hline $23-27$ & $49 \%$ \\
\hline $28-32$ & $4 \%$ \\
\hline Ethnicity: Malay & $67 \%$ \\
\hline Chinese & $16 \%$ \\
\hline Indian & $16 \%$ \\
\hline Other & $1 \%$ \\
\hline Year of Studies: $1^{\text {st }}$ & $9 \%$ \\
\hline $2^{\text {nd }}$ & $26 \%$ \\
\hline $3 \mathrm{rd}$ & $9 \%$ \\
\hline 4 th & $56 \%$ \\
\hline $\begin{array}{l}\text { Parents' Occupation: } \\
\text { Government Sector }\end{array}$ & $28 \%$ \\
\hline
\end{tabular}




$\begin{array}{ll}\text { Private Sector } & 29 \% \\ \text { Self-employed } & 36 \% \\ \text { Others } & 7 \%\end{array}$

The demographic background of the students reflects the composition of UUM students. Their age range reflects the interpretation of youth based on Youth Development and Societies Act 688. The survey also explores the forms of political involvement among respondents. The following table shows the summary of those forms of political involvement.

TABLE 2 Forms of Political Involvement

\begin{tabular}{lcc}
\hline Forms of Involvement & \multicolumn{2}{c}{ Percentage } \\
& Yes & No \\
\hline $\begin{array}{l}\text { Registered Voters } \\
\text { Encouraged others to vote }\end{array}$ & $48 \%$ & $52 \%$ \\
$\begin{array}{l}\text { Becoming voters in next } \\
\text { general election }\end{array}$ & $75 \%$ & $40 \%$ \\
$\begin{array}{l}\text { Attended any political } \\
\text { gatherings }\end{array}$ & $22 \%$ & $78 \%$ \\
$\begin{array}{l}\text { Attended any political forums } \\
\text { or talks }\end{array}$ & $34 \%$ & $66 \%$ \\
$\begin{array}{l}\text { Registered as member in any } \\
\text { political association/parties }\end{array}$ & $11 \%$ & $89 \%$ \\
$\begin{array}{l}\text { Attended any political } \\
\text { meetings to discuss any } \\
\text { relevant issue }\end{array}$ & $7 \%$ & $93 \%$ \\
$\begin{array}{l}\text { Being a committee in any } \\
\text { events organized by political } \\
\text { parties }\end{array}$ & $5 \%$ & \\
\end{tabular}

From Table 2, majority of respondents does not want to associate themselves with any forms of political involvement especially programs related to political parties like political campaign or forums. There was $95 \%$ of respondents were reluctant to be a committee in any events organized by political parties. In addition, respondents are less likely to attend any political gathering and political forums or talks. This is because the talk is organized by either governing political parties and opposition parties. This can be seen from the percentages which are $22 \%$ and $34 \%$, respectively. The reluctance to attend with those events or program may have associated with the AUKU that restricts students' involvement in politics. Even though the restriction has been lifted, students under AUKU 1971 do not want to actively involved in political activities. The finding consistent with the previous research (Mazli, Abdul Razak \& Abdul Rashid, 2019; Fazurawati, 2018). However, respondents are more comfortable to be part of basic political involvement such as registered voters and voting for choosing governing 
political parties in general election. This can be seen from the percentage which are $75 \%$ of respondents are becoming voters for the next general election while $60 \%$ of respondents encouraged others to vote in the general election. This finding is consistent with studies done by Yazid (2020) and Fauzi and Ku Hasnita (2015). The finding also indicated that $48 \%$ of respondents were registered voters. By lowering the age for eligible voters and automatic voter registration mechanism that will be implemented by Malaysian Election Council in 2021, the numbers of registered voters among youth generation will increase dramatically.

Table 3 highlights factors encourage respondents to involve in political activities.

TABLE 3 Factors encourage respondents involved in political activities

\begin{tabular}{lc}
\hline \multicolumn{1}{c}{ Factors } & Percentage \\
\hline Internet & 91.90 \\
Television & 81.30 \\
Parents & 59.40 \\
Personal interests & 51.90 \\
Radio & 39.40 \\
Education system & 38.10 \\
Mainstream newspapers & 36.90 \\
Informal social gathering & 36.30 \\
Neighbor & 31.90 \\
Political newspaper & 25.00 \\
\hline
\end{tabular}

Based on Table 3, internet has been the main contributing factor for respondents to get information about political issues. There was 91.90 of respondents choose internet as mechanism influence them to know about the political scenario. The internet in this research is specifically the use of social media and other information such as website, and online political coverage. Hong (2013) has showed that the US President Barrack Obama had won his election when he used twitter, an example of social media, as a platform to gain political advantage to do campaign and get support. Yazid (2020) also cited that website was the main source for university students to get access on current political information. In addition, social media is becoming the main source of information on current political scenario since youth prefer to use new communication technology as opposed to traditional medium of communication (Awang Besar, 2012). Political messages have been delivered by using social media like twitter, Facebook and other available platforms. For instance, the main reason why the ruling party in Malaysia had lost the election in year 2018 was due to the political campaign through social media specifically Facebook (Zawiyah \& Zalinah, 2020). The $14^{\text {th }}$ general election had witnessed the extensive used of social media like Facebook for the purpose of political campaign since its characteristics such as less concern on distance and time, borderless and huge number of Facebook users. The political campaigns, public forum, live coverage can be done via social media platform. According to PEW Research Center, some Americans are using social media as platform to encourage others and mobilize support for issues related to 
the country. In addition, there are many ways in which American can actively participate in politic via social media. There was $36 \%$ of social media users have used Facebook, Twitter and others to show support for any issues related to their daily lives. Besides, $35 \%$ of social media users look for information related to any events like rallies or protests in their community. They are using hashtag related to political issue on social media (Auxier, 2020).

Besides internet, television also contributed towards factors encourage respondents to involve in political activities. There was $81.30 \%$ of respondents choose television as one of the factors. Interestingly, other mass media like mainstream newspapers did not influence youth to participate in political settings. The finding showed that political newspaper also had the lowest score $(25 \%)$ as opposed to the mainstream newspaper (36.90\%).

In conclusion, youth plays important role towards the development of the country. They are the future leaders that are responsible to govern and maintain the wellbeing of the people in the country. Their involvement in political activities should be further emphasized because they constitute almost half of the population. Since findings show that the usage of internet and social media does attract youth to know more about political information; political parties should extensively use social media to gain supports from youth. Future research should focus on youth political involvement in formal setting. For example, the opportunities given by the political parties towards youth to actively involved in politics. In other words, the level of readiness from both government political parties and opposition political parties to provide chances for youth to hold higher positions in the parties and also as a candidate in general election. It is because the youth political involvements usually focus on assisting parties in political campaigning, rallies and voice out their concerns and opinions in social media. In other words, youth political involvement in formal setting is very limited. Findings from the 2016 UN Global youth report indicated that political party membership is lower among those under the age of 30. One fifth of world's population covers young group between 15 to 24 years. However, their participation in formal politics remain limited. There are obstacles that may contribute less participation of young people in electoral process such as political party candidates. The obstacles such as structural, individual and organizational should be uplifted in order for youth generation involve formally in politics. Malaysia needs to uphold the 2030 Agenda in which the agenda identifies youth as critical agent for change. The young generation should be included in the implementation and monitoring process of Sustainable Development Goals (SDGs) in order for country to fully utilize the youth ideas, expertise and innovations.

\section{REFERENCES}

Abdul Hadi Samsi, Amaluddin Ab Rahman and Hasnita Samsu (2013). Persepsi belia terhadap parti politik dan tahap penglibatan politik di Selangor. Malaysia Journal of Youth Studies, 9:107-120 
Abu Elnasr E Sobaih, Mohamed A Moustafa, Parvis Ghandforoush and Mahmood Khan (2016). To use or not to use? Social media in higher education in developing countries. Computers in Human Behavior, 58:296-305.

Auxier, Brooke. (13 ${ }^{\text {th }}$ July 2020). Activision on social media varies by race and ethinicity, age political party. https://www.pewresearch.org/fact-tank/2020/07/13/activism-on-social-mediavaries-by-race-and-ethnicity-age-political-party/

Awang Besar, J., Mat Jali, M. F., Ibrahim, Y., Ismail, K., Sidek, A. H., and Mohd Awal, N. A. (2012). Persepsi Belia terhadap Isu Politik dan dasar Kerajaan Malaysia. Malaysian Journal of Youth Studies, 7.

Berita Harian (2019). Retrived from https://www.bharian.com.my/berita/nasional/2019/07/58 8802/dewan-negara-lulus-pindaan-akta-turunkan-had-umur-belia-kepada-30

Berita Harian (2018). Retrieved from https://www.bharian.com.my/berita/nasional/2018/12/5 07721/pindaan -auku-diluluskan-sebulat-suara.

Carr, C. T., \& Hayes, R. A. (2015). Social media: Defining, developing, and divining. Atlantic Journal of Communication, 23: 46-65.

Eko Prayitno Joko, Zaini Othman, and Saat Awg. Damit. (2016). Belia dan kelangsungan hegemoni Barisan Nasional: Kajian Kes Pilihan Raya Umum 13 di Sabah. Jurnal Komunikasi, 14, 1-18.

Fazurawati. (2018) Kesedaran masih rendah. Retrieved from https://www.hmetro.com.my/nu ansa/2018/04/333123/kesedaran-berpolitik-masih-rendah

Jamaie Hj Hamil, et. al. (2014). Ikhtisar Analisis Pilihan Raya Umum 1978 hingga 2013 di Malaysia. Malaysian Journal of Society and Space 10:39-53

Mohd Fuad Mat Jali, Junaidi Awang besar, Novel Lyndon \& Viknesh a/l Ramachandran. (2012). Perspesi politik belia India di Institusi Pengajian Tinggi Awam (IPTA) Malaysia. Malaysia Journal of Society and Space 8 issue 8:1-11

Hong, S. (2013). Who benefits from Twitter? Social media and political competition in the U.S. House of Representatives. Government Information Quarterly, 30(4), 464-472

Hamid, S. A. (2016). Pengaruh Media Massa Terhadap Perubahan Sosial Masyarakat. Journal of Social Sciences and Humanities, 214-226.

Howard, P. N. (2006). New media campaigns and the managed citizen. New York, NY: Cambridge University Press.

Junaidi Awang Besar, Rosmadi Fauzi, Amer Saifude Ghazali and Muhammad Hazim Abdul Ghani. (2014). Persepsi politik dalam Pilihan Raya Umum 2013: Kajian kes di Wilayah Persekutuan Kuala Lumpur. Journal of Social Sciences and Humanities, 9(2), 135-161 
Junaidi Awang Besar, Mohd Fuad Mat Jali, Yahaya Ibrahim, Khaidzir Ismail, Abdul Halim Sidek, and Noor Aziah Mohd Awal. (2012). Persepsi belia terhadap isu politik dan dasar kerajaan Malaysia. Malaysian Journal of Youth Studies, 7, 136-156

Kitanova, M. (2019). Youth political participation in the EU: Evidence from a cross-national analysis. Journal of Youth Studies, 23(7):819-836

Kreiss, D. (2016). Seizing the moment: The presidential campaigns' use of Twitter during the 2012 electoral cycle. New Media \& Society, 18, 1473-1490. doi:10.1177/1461444814562445

Marshelayanti Mohammad Razali, S. N. (2016). Penglibatan Politik Belia: Satu Analisis Penyertaan Konvensional di Malaysia . Jurnal Perspektif , 75.

Mazli, M., Rahman, A. R. A., and Abdullah, A. R. (2015). Penglibatan mahasiswa melayu universiti awam dalam politik di Malaysia. Malaysian Journal of Youth Studies (13), 2331.

Ninth Malaysia Plan (206-2010). Retrieved from: http://www.epu.gov.my/en/economicdevelopments/development-plans/rmk/ninth-malaysia-plan-2006-2010

Norshuhada Shiratuddin, Mohd Azizuddin Mohd Sani, Shahizan Hassan, Mohd Khairie Ahmad, Kartini Aboo Talib @ Khalid, Noor Sulastry Yurni Ahmad. (2016). Generation Y's Political Participation and Social Media in Malaysia. Jurnal Komunikasi, 32(1) 2016:125-143.

Nor Anita Abdullah. (2017). Belia vs mahasiswa: Pengaruh sosialisasi politik. Journal of Humanities, Language, Culture and Business, 1(4), 127-134.

Saad, S., and Salman, A. (2013). The Role of Values and Attitudes in Political Participation. Asian Social Science, 9(8). doi:10.5539/ass.v9n8p9

Saleem Alhabash and Mengyan Ma. (2017). A tale of four platforms: Motivations and uses of facebook, twitter, Instagram, and snapchat among college students? Social Media + Society, January-March, 1-13. ps://doi.org/10.1177/2056305117691544

Seventh Malaysia Plan (1996-2000). Retrieved from http://www.epu.gov.my/en/economicdevelopments/development-plans/rmk/seventh-malaysia-plan-1996-2000

Siti Noranizahhafizah Boyman. (2017). Students and Campus Elections: Case study at Sultan Idris Education University, Malaysia. International Journal of Humanities and Social Sciences, 9(6), 32-45.

Sivamurugan Pandian. (2014). University students and voting behavior in general elections: Perceptions on Malaysian political parties leadership. Asian Social Science, 10(18), 225231.

Yaakop, R. T. (2017). Penglibatan Mahasiswa Dalam Protes Politik di IPTA PRK 2016. Journal of Social Sciences and Humanities, 104-115. 
Yazid Saleh, Siti Noranizahhafizah Boyman, Hanifah Mahat, Mohmadisa Hashim, Nasir Nayan Saiyidatina Balkhis Norkhaidi, and Samsudin Suhaili. (2020). Pola sokongan pengundi muda sebelum Pilihan Raya Umum ke 14 di Malaysia. GEOGRAFIA Malaysian Journal of Society and Space, 16(1), 80-94.

Youth Participation in Electoral Processes - Handbook for Electoral Management Bodies. $\left(3^{\text {rd }}\right.$ July 2017). Retrieved from https://www.undp.org/content/undp/en/home/librarypage/de mocratic-governance/youth-participation-in-electoral-processes-a-handbook-forembs.html

Zawiyah Mohd Zain and Zalinah Ahmad (2020). The using of facebook in Malaysia's $14^{\text {th }}$ general election: An anlysis of INVOKE. Proceedings of the Second International Conference on Social, Economy, Education and Humanity (ICoSEEH 2019) - Sustainable Development in Developing Country for Facing Industrial Revolution 4.0,421-425. ISBN:978-989-758-464-0

\section{About the authors}

Zalinah Ahmad is currently a Senior Lecturer at School of Government, Universiti Utara Malaysia. Her research interests include policy implementation studies, youth studies and nongovernmental organizations.

Associate Professor Dr. Zawiyah Mohd Zain is currently attached to Universiti Utara Malaysia and hold PhD degree in Political Science from Universiti Kebangsaan Malaysia in 2013. Her research interests include Malaysian politics, democratization and civil disobedience. 